\title{
A case of spinal tuberculosis from the Middle Ages in Transylvania
}

\section{(Romania)}

Tamás Hajdu, MSc ${ }^{1}$, Helen D. Donoghue, $\mathrm{PhD}^{2,3}$, Zsolt Bernert, $\mathrm{MSc}^{4}$, Erzsébet Fóthi, $\mathrm{PhD}^{4}$, Ivett Kővári, $\mathrm{PhD}^{5}$, Antónia Marcsik, $\mathrm{CSc}^{6}$

${ }^{1}$ Department of Biological Anthropology, Institute of Biology, Faculty of Science, Eötvös Loránd University, Pázmány Péter sétány 1/C, H-1117 Budapest, Hungary;

${ }^{2}$ Centre for Clinical Microbiology (M9), Royal Free Campus, University College London, London, UK

${ }^{3}$ Centre for the History of Medicine, University College London, London, UK

${ }^{4}$ Department of Anthropology, Hungarian Natural History Museum, Ludovika tér 2, H-1083 Budapest, Hungary;

${ }^{5}$ Department of Archaeology, Herman Ottó Museum, Görgey Artúr str. 28, H-3529 Miskolc, Hungary;

${ }^{6}$ Retired associate professor, University of Szeged, Mályva utca 23, H-6771 Szeged, Hungary; Corresponding author: Tamás Hajdu, Department of Biological Anthropology, Institute of Biology, Faculty of Science, Eötvös Loránd University, Pázmány Péter sétány 1/C, Budapest, Hungary, H-1117. Tel.: 00-36-1-381-21-61. e-mail: hajdut@elte.hu

The manuscript submitted does not contain information about medical device(s)/drug(s). No funds were received in support of this work. No relevant financial activities outside the submitted work.

\section{Abstract}

Study Design: Case report. 
Objective: To characterise the paleopathology presented in the skeleton of a 45-50-year-old male indicative of tuberculous spondylitis and to confirm by the detection of ancient DNA.

Summary of Background Data: Tuberculosis (TB) is an infectious disease prevalent in both present and ancient human populations. The disease is primarily located within the lungs, so although characacteristic bone lesions can lead to a clear diagnosis, skeletal TB occurs in only $5-6 \%$ of TB infections, even in historical cases. In addition, the visual appearance of human skeletal remains may be influenced by the environmental conditions at the burial site. However, it is important to recognise ancient skeletal TB, because this can provide important data on the history of Mycobacterium tuberculosis and gives an unique opportunity for physicians to observe the natural outcome of the infection from the pre-antibiotic era.

Methods: Paleopathological analysis was carried out using careful visual observation supported by ancient DNA analysis. Approximately $60 \mathrm{mg}$ of bone powder from rib fragments was examined and DNA from the M. tuberculosis complex was detected by PCR targeting specific genetic loci of the IS6110 and IS1081 regions.

Results: The skeleton is part of a human osteoarchaeological collection $(n=274)$ from the 12th-13th century Transylvanian archaeological site of Peteni, in modern-day Romania. The individual, a 45-50-year-old male, showed gross pathology typical of tuberculous spondylitis. The paleopathological diagnosis was supported by analysis for M. tuberculosis complex ancient DNA.

Conclusions: This case demonstrates that TB was present in Transylvania (Romania) during the 12-13th century and adds to the growing body of knowledge on the history of this disease. Key Words: ancient DNA;Mycobacterium tuberculosis complex, paleopathology, PCR, skeletal tuberculosis, Transylvania (Romania)

\section{Mini Abstract/Précis.}


The skeleton of a 45-50-year-old male from the 12-13th century in Transylvania, present-day Romania, demonstrated paleopathology typical of spinal tuberculosis. The morphological diagnosis was supported by the detection of ancient DNA specific for the Mycobacterium tuberculosis complex.

\section{Key Points:}

Spinal tuberculosis was present during the 12-13th century in Transylvania.

The presented case was examined morphologically and supported by the detection of ancient DNA from the Mycobacterium tuberculosis complex.

\section{Introduction}

Tuberculosis (TB) is an infectious disease caused by members of the Mycobacterium tuberculosis complex. The infection is normally located within the lungs. However, the infection may become generalised and affect the skeleton, mainly the thoracic and the lumbar sections of the spine, the great joints, the costae and the endocranial surface. Skeletal TB is, with rare exceptions, the result of limited hematogenous spread. ${ }^{1}$

The appearance of ancient TB in Europe, including Hungary and the whole Carpathian Basin, has been the subject of several previous investigations. ${ }^{2-6}$ From Romania only four cases have been published which describe bone alterations suggestive of $T B$, from the Medieval cemetery of Sibiu-Piața Huet. ${ }^{7}$

The purpose of the current study is to present a new skeletal TB case from Transylvania, in present-day Romania.

\section{Material and methods}

A human osteoarchaeological collection $(n=274)$ dated to the 12-13th century, from the Transylvanian archaeological site of Peteni, ${ }^{8}$ served as a source of material. The age at death and the morphological sex was estimated based on the method of Acsádi and Nemeskéri. ${ }^{9}$ Grave 107 contained the skeleton of a 45-50-year-old male which showed possible 
pathological changes. A paleopathological visual analysis was followed up with ancient DNA (aDNA) analysis for the Mycobacterium tuberculosis complex.

Molecular analysis of DNA for the Mycobacterium tuberculosis complex

Rib fragments were used for DNA extraction. The recommended protocols for aDNA were followed and approximately $60 \mathrm{mg}$ of bone powder was examined and DNA extracted. ${ }^{5,10}$ PCR was used to amplify any DNA from specific regions of the multicopy IS6110 and IS1081 regions of the M. tuberculosis complex. Amplified DNA was examined by agarose gel electrophoresis and confirmed by sequencing. ${ }^{10,11}$

\section{Results}

\section{Paleopathological assessment}

Cervical $(C)$ spine: From $\mathrm{C} 1$ to $\mathrm{C} 6$ all vertebrae are absent post-mortem. A 8-9 $\mathrm{mm}$ wide probable lytic hole can be observed on the superior surface of the corpus of C7.

Thoracic (T) spine: T1, T2 and T6 are absent post-mortem. The superior surface of T3 is porotic and pitted. There are two small pits on the superior surface of T4. The corpus is porotic and the inferior surface is eroded (Fig. 1). The inferior surface of T5 is pitted. Onequarter of the inferior surface of $\mathrm{T} 7$ is missing due to lytic destruction. This reduced the height of the corpus so the corpus has started to collapse (Fig. 2). The superior surface of T8 and the inferior surface of T11 are pitted. There is one major lytic hole on the inferior surface of T9.

Lumbar $(L)$ spine: Slight spondylosis deformans can be seen on L1 - the inferior surface of the corpus is pitted (Fig. 3). Osteophyte formation can be seen on the right side of L2 and the height of the corpus is reduced. The inferior surfaces of the corpus of L2 and L3 are pitted. Besides possible post-mortem changes, large pre-mortem perforations can be seen on the corpus of L3. The height reduction of the corpus is major. There are more cavities in the corpus of L4 (Fig. 4). The cavities are smaller on the inferior surface than the superior surface 
and also the height of the corpus is reduced. The superior surface of the corpus of L5 is eroded by smaller pits and a major cavity has formed. Osteophyte formation appears between the left side of the corpus of L5 and the sacrum.

Ribs: No active periosteal reactions were observed on the ribs. However, on the costal groove and on the inner surfaces of the ribs, disseminated small new bone formations (probably healed pleuritis/periosteal appositions) can be seen (Fig. 5).

Endocranial surfaces, pelvic girdle and the bones of the lower limbs: No pathological changes consistent with any possible infectious diseases were observed on these bones.

Diagnosis: Possible spinal TB. However, other infectious processes cannot be excluded.

\section{Molecular examination}

Positive PCR results were obtained using primers for IS6110 (123-bp) and IS 1081 (113-bp)

(Fig. 6). The IS1081 amplified DNA was sequenced (Figs. 7A-B) which confirmed that it was from the M. tuberculosis complex.

\section{Conclusions}

Ancient skeletal TB has been described previously in the Carpathian Basin. ${ }^{5,6}$ Based on morphological and molecular results, this Transylvanian case from the Medieval Period, in present-day Romania, contributes to our knowledge on the paleopathology of spinal TB and its occurrence in the Carpathian Basin in the past.

\section{Acknowledgments}

We acknowledge those who assisted this work, including Sándor József Sztáncsuj, Loránd László Méder and Elek Benkő. We also thank Zsigmond Loránd Bordi, the former leader of the Archaeological Department of Székely National Museum, in Sf. Gheorghe Romania, for permission to examine the Peteni anthropological material. 


\section{References}

1. Ortner DJ. Identification of a pathological conditions in human skeletal remains. San Diego: Academic Press. 2003.

2. Pálfi Gy, Marcsik A. Paleoepidemiological data of tuberculosis in Hungary. In: Pálfi Gy, Dutour, O, Deák, J, Hutás, I. eds. Tuberculosis Past and Present. Budapest: Golden Book Publisher Ltd., Tuberculosis Foundation. 1999: 533-542.

3. Pálfi Gy, Dutour, O, Deák, J, Hutás, I. eds. Tuberculosis Past and Present. Budapest: Golden Book Publisher Ltd., Tuberculosis Foundation. 1999.

4. Marcsik A, Molnár E, Szathmáry L. The antiquity of tuberculosis in Hungary: the skeletal evidence. Mem Inst Oswaldo Cruz 2006;107(Suppl. II):67-71.

5. Évinger S, Bernert Zs, Fóthi E, Wolff K, Kővári I, Marcsik A, Donoghue HD, O’Grady J, Kiss KK, Hajdu T. New skeletal tuberculosis cases in past populations from Western Hungary (Transdanubia). Homo 2011;62:165-183.

6. Köhler K, Pálfi Gy, Molnár E, Zalai-Gaál I, Osztás A, Bánffy E, et al. A late Neolithic case of Pott's disease from Hungary. Int J Osteoarchaeol 2012; 'Accepted Article', doi: 10.1002/oa.2254

7. Marcu Istrate D, Soficaru AD, Constantinescu M. The medieval cemetery from SibiuPiața Huet. Anthropological and archaeological perspectives. Tübingen. 2012, in press.

8. Székely Z. Korai középkori temetők Délkelet-Erdélyben. In: Székely Zs, Tárnoki J (eds): Székely Zoltán válogatott tanulmányai. Szolnok Megyei Múzeumi Adattár 35, Szolnok: Jász-Nagykun-Szolnok Megyei Múzeumok Igazgatósága. 2001:164-171.

9. Acsádi Gy, Nemeskéri J. History of human life span and mortality. Budapest: Akadémiai Kiadó. 1970. 
10. Hershkovitz I, Donoghue HD, Minnikin DE, Besra GS, Lee OY-C, Gernaey AM, et al. (2008). Detection and molecular characterization of 9000-year-old Mycobacterium tuberculosis from a Neolithic settlement in the Eastern Mediterranean. PLoS ONE 2008;3(10):e3426-e3426.

11. Donoghue HD, Lee OY-C, Minnikin DE, Besra GS, Taylor JH, Spigelman M (2010). Tuberculosis in Dr Granville's Mummy: a molecular re-examination of the first Egyptian mummy to be scientifically examined and given a medical diagnosis. Proc Biol Sci 2010;277:51-56.

\section{Figure legends}

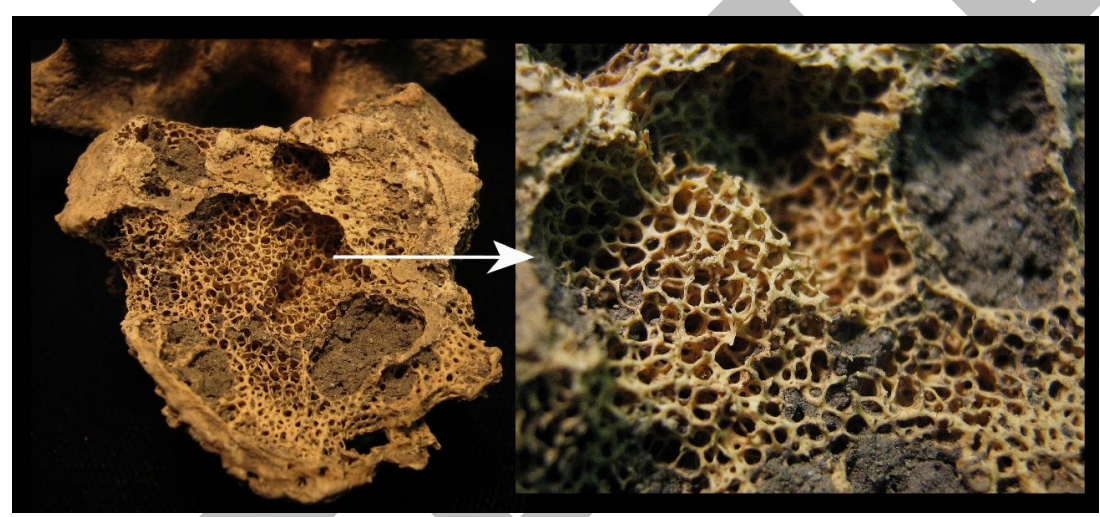

Figure 1. The inferior surface of the corpus of the 4th thoracic vertebra is eroded by lytic holes.

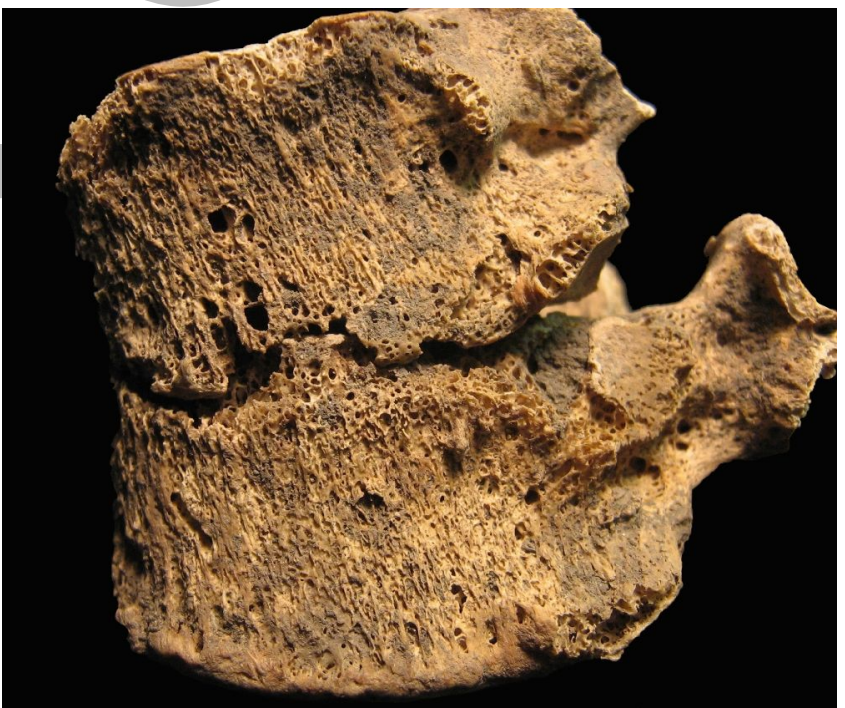


Figure 2. The height of the corpus of the 7th thoracic vertebra is reduced and a collapse started to form.

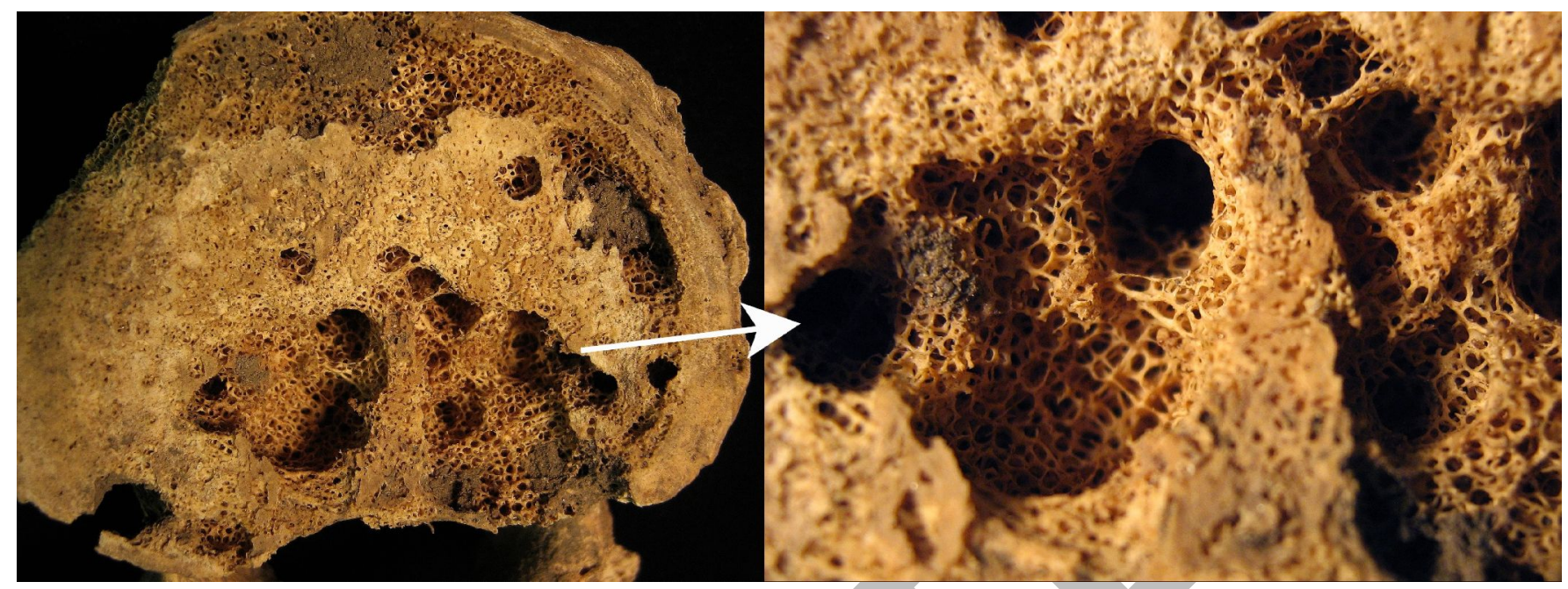

Figure 3. The inferior surface of the corpus of the first lumbar vertebra is pitted.

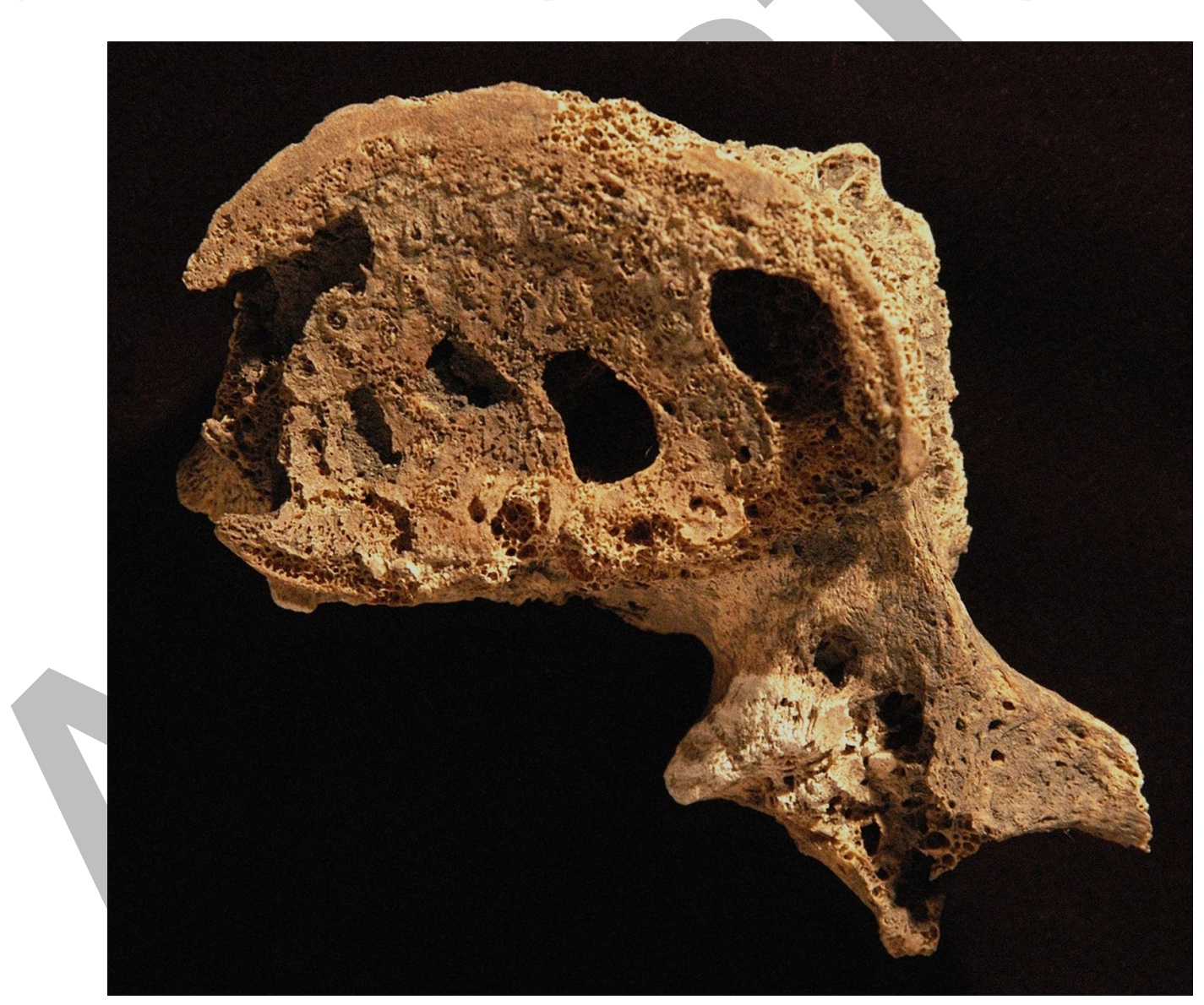

Figure 4. More cavities can be seen on the inferior surface of the 4th lumbar vertebra (the photo was taken by Elek Benkö). 

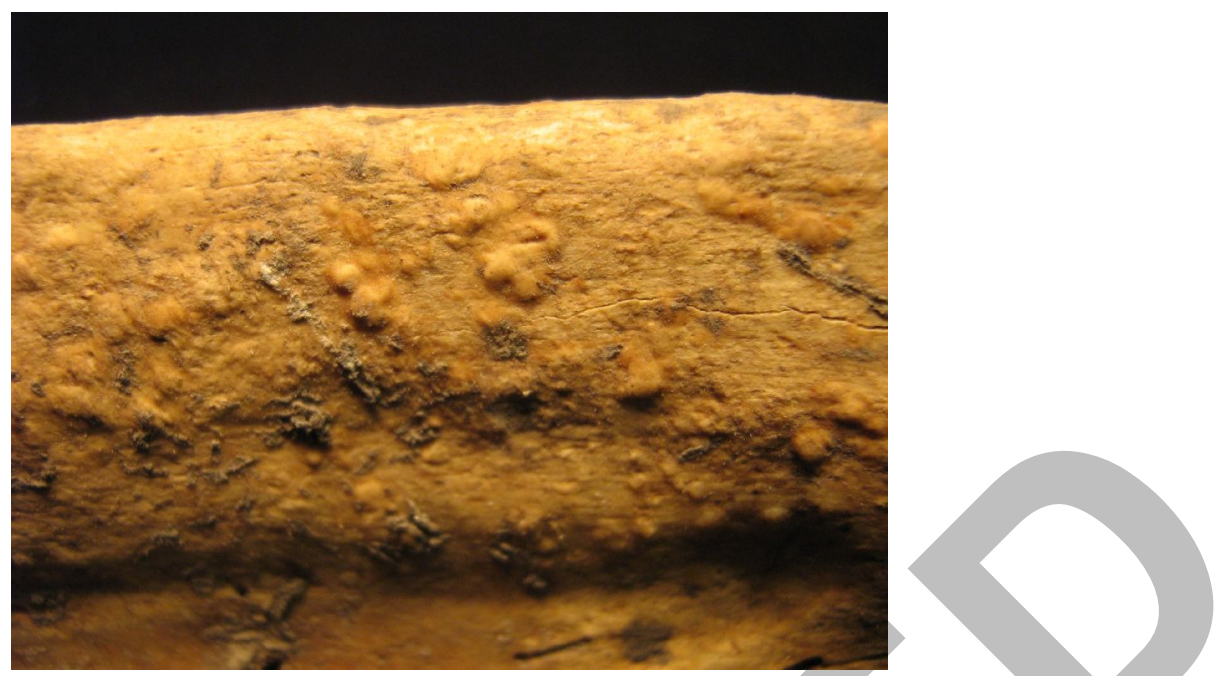

Figure 5. Disseminated small new bone formations can be observed on the costal groove and on the inner surface of the ribs.
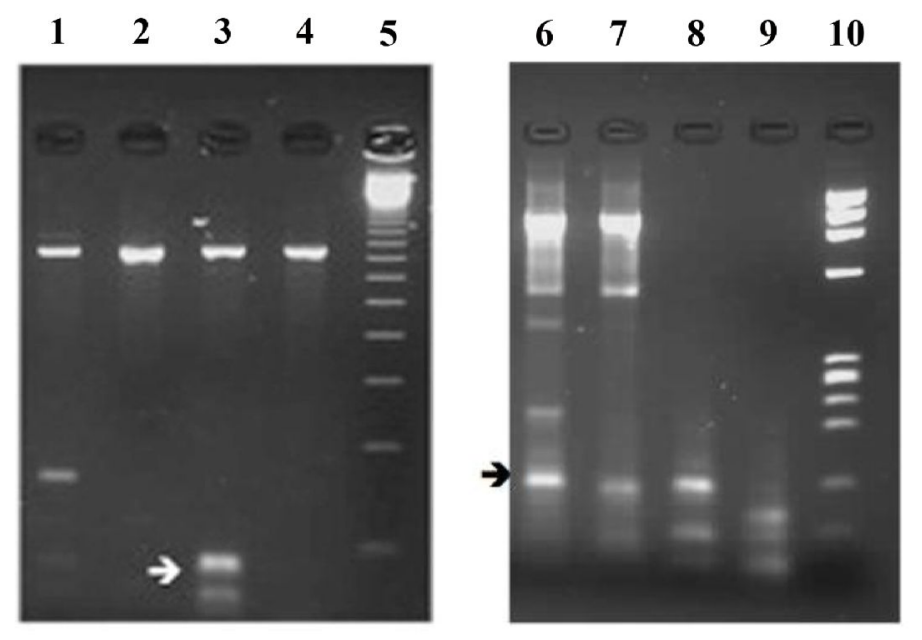

Figure 6. Agarose gel electrophoresis of PCR amplicons from the M. tuberculosis complexspecific loci IS6110 (on the left side) and IS1081 (on the right side). The gels were loaded as follows (left to right): lanes 1-3, different fractions of DNA extract from Peteni 107 (see white arrow); lane 4, negative extraction control; lane 5, molecular markers, lanes 6-9, different fractions of DNA extract from Peteni 107 (see black arrow), lane 10, molecular markers. 


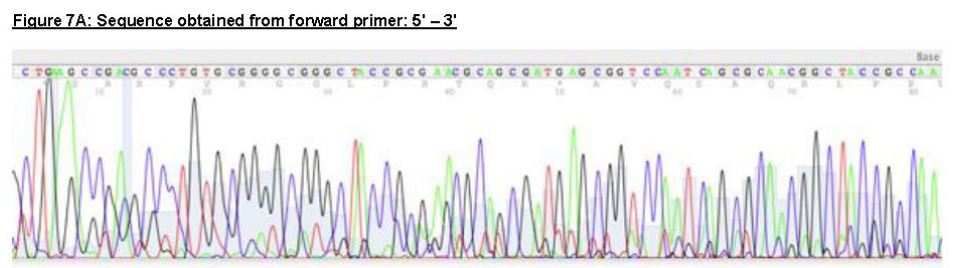

Sbjct 35 CTGAAGCCGACGCOCTGTGCGGGGCGGGCTACCGCGAACGCAGCGATGAGCGGTCCAATC 94 Query 14 CTGAAGCCGACGCOCTGTGCGGGGCGGGCTACCGCGAACGCAGCGATGAGCGGTCCAATC 71

Sbjct 95 AGCGCAACGGCTACCGCCA 113

111111111111111111111
Query 72 AGCGCAACGGCTACCGCCA 90

CTG CTC TCG ACG TTC ATC GCC GCC TTG ATG GGG GCT GAA GCC GAC GCC CTG TGC GGG GCG GGC TAC CGC GAA CGC AGC GAT GAG CGG TCC AAI CAG CGC AAC GGC TAC CGC CA

Figure 7B: Sequence obtained from reverse primer: $3^{\prime}-5^{\prime}$

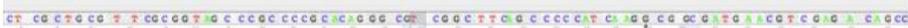

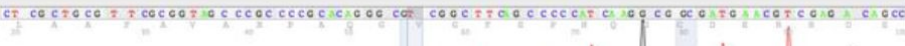

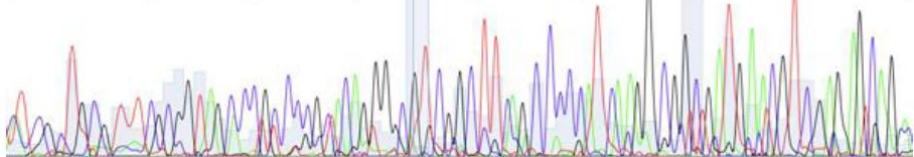

Sbjct 1 CTGCTCTCGACGTTCATCGCCGCCTTGATGGGGGCTGAAGCCGACGCCCTGTGCGGGGCG

Query 79 CTG-TCTCGACGTTCATCGCCGCCTTGATGGGGGCTGAAGCCGACGCCCTGTGCGGGGCG 21

Sbjct 61 GGCTACCGCGAACGCAGCGA 80

Query 20 GGCTACCGCGAACGCAGCGA

TGG CGG TAG COG TTG CGC TGA TTG GAC CGC TCA TCG CTG CGT TCG CGG TAG COC GCC CCG CACAGG GCG

Figure 7. DNA sequences obtained from the M. tuberculosis complex specific region of IS1081. For the forward (Fig. 7A) and reverse (Fig. 7B) primers the following data are shown: Top: the actual sequence (electropherogram); Centre: the experimental sequence obtained by PCR aligned with the corresponding sequence in the NCBI nucleotide database (http://www.ncbi.nlm.nih.gov/nucleotide/); Bottom: the forward and reverse sequence for the target locus showing the primers (underlined) and the bases sequenced from amplified DNA (blue text). 